\title{
Complications in Breast Reduction
}

Editor

DENNIS C. HAMMOND

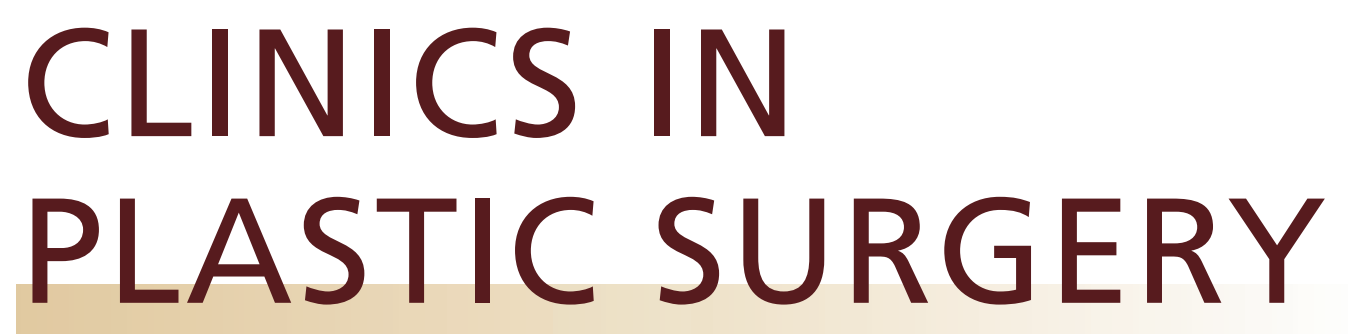

www.plasticsurgery.theclinics.com

April 2016 - Volume 43 - Number 2 